\title{
Private Disclosure and Corporate Value Creation
}

\author{
YANTI PUJI ASTUTIE* \\ Universitas Pancasakti Tegal \\ ANIS CHARIRI \\ SITI MUTMAINAH \\ Diponegoro University
}

\begin{abstract}
The primary objective of this paper is to investigate the content of disclosure using a critical case study. Private disclosure has a content structure, and it is useful in processing value creation. By doing private disclosure, the information on intellectual capital gets perceived by market participants. Disclosure Transformation Theory (Alberti-Alhtaybat, Hutaibat, \& Al-Htaybat, 2012) was tested through the observation and analysis of the private disclosure functions. This study also expands the view of how the narrative of the corporate value creation is structured and how corporate knowledge becomes an essential part of the dynamic response of the disclosure that changed over time. This study observes new findings regarding intellectual capital disclosure as well as disclosure content in PT. Bank Negara Indonesia Tbk (BNI). BNI has disclosed information value creation in three processes; hierarchy, horizontal, and network, by organizing private disclosure media in order to respond to user information needs. This agenda uses analysts as information mediators. Otherfindings are that private disclosure is a source of information that creates information toward a market context of participants to interpret the information more appropriately. The information in private disclosure has superior knowledge in the initial formulation, and in controlling the portfolio risk of assets allocation to the analyst. Private disclosure has essential implications for regulatory policies regarding insider information, corporate disclosure, and corporate governance in financial institutions.
\end{abstract}

Keywords: Private Disclosure, Intellectual Capital, Disclosure Content, Value Creation.

Abstrak-Penelitian ini bertujuan menggali lebih dalam disclosure content dengan menggunakan pendekatan studi kasus krusial. Pengungkapan privat diketahui memiliki struktur dan merupakan hal yang penting dalam proses penciptaan nilai. Dalam pengungkapan privat, informasi intellectual capital menjadi terlihat oleh para pelaku pasar. Disclosure Transformation Theory (Alberti-Alhtaybat et al., 2012) diuji melalui observasi dan analisis atas fungsi pengungkapan privat mengenai struktur narasi dalam penciptaan nilai perusahaan. Penelitian ini juga memperluas pandangan tentang bagaimana narasi penciptaan nilai perusahaan yang terstruktur serta bagaimana pengetahuan perusahaan telah menjadi suatu hal penting atas respon dinamis pengungkapan, dan telah mengalami perkembangan seiring waktu.

\footnotetext{
*Corresponding author: yanti.accounting@upstegal.ac.id
} 

Penelitian ini mengobservasi narasi mengenai modal intelektual dalam pengungkapan privat serta konten pengungkapan di PT Bank Negara Indonesia Tbk. BNI telah melakukan keterbukaan informasi melalui tiga proses penciptaan nilai, yaitu: hirarkis, horizontal, dan network dengan cara membentuk media pengungkapan privat dalam upaya memberikan respon atas kebutuhan informasi pengguna. Agenda tersebut menggunakan analis investasi sebagai pihak mediator informasi. Temuan penelitian ini diantaranya adalah bahwa pengungkapan privat merupakan sumber informasi dan dapat menciptakan konteks informasi bagi pelaku pasar modal dalam menafsirkan makna atas informasi dengan cara yang lebih tepat. Informasi dalam pengungkapan privat memiliki keunggulan pengetahuan dalam perumusan awal serta masukan penting dalam pengendalian risiko portofolio dan alokasi aset bagi analis. Pengungkapan privat memiliki implikasi penting bagi kebijakan regulasi mengenai informasi orang dalam, pengungkapan perusahaan, dan tata kelola perusahaan pada institusi keuangan.

Kata Kunci: Pengungkapan Privat, Modal Intelektual, Disclosure Content, Penciptaan Nilai

\section{Introduction}

Corporate disclosure is vital in implementing efficient capital markets. The company provides disclosures through pre-arranged financial reports and the fulfillment of documents to regulators. Scott $(2009$, p. 445) stated that there were two types of information held by managers, namely specific information and non-specific information. As an effort to expand disclosures, some companies also conducted voluntary communication such as forecasting, analyst presentations and conferences, press releases, news on the website and the internet, and other company reports. Whereas Healy and Palepu (2000, p. 19-29) stated that the other way of voluntary disclosures were disclosures through information intermediaries, such as Investment Managers, industry experts, and financial media.

The company has a choice of whether or not to do voluntary disclosure by carrying out initial considerations. Non-financial disclosures have an influence on corporate governance and risk management as well as value drivers. The approach taken in non-financial disclosures is expected to produce reasonable, scheduled disclosure properties and provide low-cost access for users. Positive accounting theory Watt and Zimmerman (1985, p. 113) answered the reasons why companies made 
voluntary disclosures caused by the personal interests of managers. However, this study had an interest based on specific reasons for disclosure, which illustrated the changes in the demand and supply side of information on the market. Healy and Palepu (2000, p. 19-29) suggested that there were several motives in making voluntary disclosures for management, namely capital market transactions, corporate control struggles, stock compensation, demand avoidance, ownership costs, and signal management expertise. Increasing the credibility of voluntary disclosure can be done in two ways, such as meeting with third parties, namely information intermediaries or analysts who can provide assurance for the quality of management disclosure and prove the validation of previous voluntary disclosure through required financial reporting.

One type of voluntary disclosure activity carried out by the company is conducting private disclosures, namely activities in the form of meetings and dialogues with Investment Managers and analysts, which discuss matters that are considered relevant by the company and need to be disclosed. Meetings are held at times after the company conducts annual information disclosure. This study emphasizes the discussion of intellectual capital at the meeting. Private disclosures produce company narratives or presentations that are expected to get a reaction from analysts and are followed by shareholders to create corporate value. Private disclosure is the disclosure stage before the publication of the company's voluntary disclosures. Private disclosures also have structures and narratives that need to be explored more deeply because markets are often unaware of the direction of contextual information contained in them. Therefore, the motivation of this study is a deeper understanding of the structure, narrative, and contextual information on private disclosure content. There are still few studies that discuss private disclosures, especially those associated with the process of creating corporate value to find out the nature and testing of disclosure content theory proposed by Holland (2004).

PT. Bank Negara Indonesia, Tbk. (BNI) is one of the companies that has experienced the development of information needs and has made efforts to expand information disclosure with private disclosure. Private disclosures are conducted 
periodically every three months, and the presented results are published on the BNI website. As a company in the banking industry, BNI has human resources as the principal capital of its operations.

Moreover, lately, intellectual capital has experienced rapid development and has become an essential role in value leverage. Intellectual capital is difficult to be measured financially but has considerable implications for company valuation. Banking service companies such as BNI certainly use the intellectual capital optimally and report their development efforts as a form of expansion of disclosure. In stock trading on the exchange, BNI has always been a daily top value of trade. For this reason, BNI was chosen as the research setting.

With the situation developing in the company as well as differences in the environment and the condition of the country where the company operates, the existing theories have different developments, including the subject of disclosure content. This thought raises several research questions as follows; What are the situations and processes that occur during the private disclosure process at PT. Bank Negara Indonesia, Tbk?

\section{Research Model Framework}

\subsection{Private Disclosure}

Private disclosure is an activity in the form of meetings and dialogues with analysts, which discuss matters that are considered relevant by the company and need to be revealed. Things that are often discussed in the meeting are information about the achievement of strategies and results of company performance and intellectual capital as part of a strategy that is not disclosed in the Annual Report. Meetings are held at times after the company conducts the annual information disclosure. Private disclosure includes a broad agenda and informal qualitative information about intangible corporate assets such as management quality, strategy and inherent matters, recent changes in strategy and succession, and management style. Holland (1998a, 2001, 2002, 2006) and Holland and Johanson (2003) stated how analysts' judgments, 
private disclosures, and the significance of intangible assets were emphasized in qualitative factors in company valuations.

Holland (1998b, p. 255-69), Marston (1996), and Barker (1997) stated that private disclosure and dialogue had been used to close the information gap regarding intangible assets by issuing qualitative information on the part seen in the company value creation process. Extensive information on voluntary disclosure has resulted in discretionary disclosure (Guttman, Kremer, \& Skrzypacz, 2012). This causes the company to choose the method of disclosure through a formal and informal information agenda. The company then chooses to change the balance of voluntary disclosure through the informal agenda in the form of one-on-one meetings with analysts. The results of meetings with the analysts are presented in the form of qualitative information with narratives that describe the process of creating corporate value. The information is expected to be immediately responded by analysts in the form of valuations and company forecasting, which will be followed by investor responses in the market. After the company does the presentation, the results of the presentation and analyst forecasting will be published to the public as part of voluntary disclosure. Private disclosure is a crucial stage before the publication of voluntary disclosures.

\subsection{Intellectual Capital}

The definition of intellectual capital (IC) which is widely used is the definition offered by the Organization for Economic Co-operation and Development (OECD, 1999) which describes IC as the economic value of two categories of intangible assets: (1) organizational (structural) capital, and (2) human capital

Organizational (structural) capital refers to things such as software systems, distribution networks, and supply chains. Human capital includes human resources within the organization (i.e., labor/employee resources) and external resources related to the organization, such as consumers and suppliers. Often the term IC is treated as a synonym for intangible assets. Nevertheless, the definition presents quite a difference by putting the IC as a separate part of the basis for determining the overall intangible 
assets of a company. Luthy (1999) stated that the basic concept of importance in this definition, including the idea that intellectual capital was knowledge-based, captured in a form and could be identified, and useful for the organization. Intellectual capital is not only easily available but also includes the ability of a human's brain. Definition and basic concepts provide a useful basis for understanding the intellectual capital.

\subsection{The main role Narrative of Value Creation in Disclosure Strategy}

The narration text of disclosure is carried out in the categorization of broad value creation, so it summarizes much information. The size of subjective and objective benchmarks of intangible assets provides further information on the structure of the disclosure (Holland, 2006). The narrative text is used to express information and relate to the value creation process, while the entire structure in it conveys contextual information. Contextual information is information that has an element of emphasis and includes the process of value creation carried out in the disclosure.

\subsection{Value Creation Process}

The process of network value creation explains how companies create a variety of knowledge-intensive competencies that are shared at the company's boundaries. General knowledge-intensive competence commonly covers various things, both tangible and intangible value as drivers through supply, production alliances, and marketing at various points in the company's value creation process. Also, it also includes the distribution of intangible assets through fixed transaction relationships with suppliers, distribution, and sales around the horizontal value creation chain. Strategic narrative texts are connected with various critical elements in the value creation process. These fundamental elements are communicated externally to analysts through narrative texts that connect the process of hierarchical, horizontal, and network value creation.

\subsection{Literature Regarding the Value Creation Process}

There are only a few literatures that discuss how companies organize their private disclosures in the financial markets. Among them are Arnold's, Moizer's, and Noreen's 
(1984), which emphasize the direct value of companies for Investment Managers (MI) in the UK. This research provides new insights into the content of intangible assets and qualitative information on the new disclosure agenda. Chugh and Meador (1984) also did the same for MI in America and produced significant records of MI's direct relations hip with the company. Marston (1996) showed how companies perceived the relative importance of private disclosures they did in the information of a different type in the company's prospects. Three important things discussed in the study were long-term corporate strategy, short-term corporate strategy, and corporate strategy in different business segments.

In terms of perceptions of private disclosures of different types of past information, three main agendas are explained, namely; current results, balance sheet and completeness, and performance on the latest acquisitions. While Barker (1997) discovered findings that formal and direct relationships with senior management of the company were essential sources of information for investment managers, while financial statements and accountants were the second primary source of information. Special meetings between MI and top management were felt important in bringing fund managers to understand the company's strategy and assess the company's capacity to achieve the strategy. Furthermore, Holland (1998b) described the communication of 25 companies in the UK with their principal shareholders, namely financial institutions. This research focuses on the flow of information on private disclosures from companies that are invested in institutional investors. The above studies have provided some insight into the content of disclosures, especially corporate communications on intangible assets that play a role in the creation of corporate values. (Alberti-Alhtaybat \& Al-Htaybat, 2016) stated that the era of 2.0 investor relations used more web to disclose information. But the willingness of companies to use social media had potential risks in addition to the benefits that must be anticipated 


\subsection{Research Model Framework}

Figure 2.1

Research Framework

Crucial Case Study

Excavation of Private Disclosure Content at PT. Bank BNI (Persero), Tbk

Disclosure Transformation Theory

(Alberti - Alhtaybat, Hutaibat, \& Al - Htaybat, 2012)

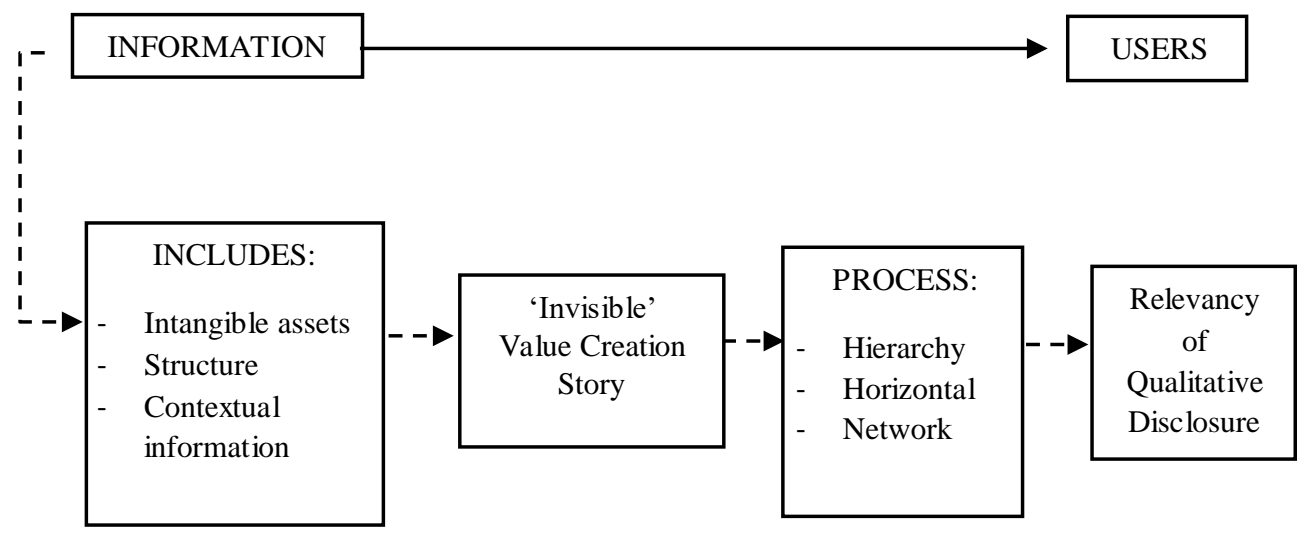

The excavation of private disclosure narrative aims to test and support disclosure transformation theory. The narrative that is the subject of this research is intellectual capital. Observations are made to find out how the relevant information can reach the user and reveal things that are not seen to be visible on the market in the process of creating value for the company. The structure, narrative text, and contextual information on private disclosure are formed by two factors: intervening conditions and causal conditions. These conditions include environmental knowledge, market changes, and company conditions, changes in the external market information and capital market, the dynamic nature of relevant disclosures and literature, and changes 
in the quality of disclosure content. These conditions are not impossible to experience developments or changes due to differences in sample companies with market conditions with different Efficiency Market Hypothesis (EMH).

\section{Research Method}

\subsection{Research Design}

The research design used is a critical case study, which is a case study that seeks to dig deeper into the case of disclosure of content in the disclosure of private enterprise. After the problem and the research, the question is built, and the theory that we want to test is examined, the next step is selecting the sample that uses the unit of analysis on one particular company. According to Denzin and Lincoln (2009, p.3013), case studies are not a methodological choice, but rather as the choice of the object under study. As a form of research, case studies are determined by interest in individual cases, not determined by the research methods used.

\subsection{Data and Data Sources}

The data used are in the form of symptoms, and events which are then analyzed in the form of categories. Data consisted of primary and secondary data types. Data are collected in the following ways: 1) In-depth Interviews, 2) Observation and 3) Assessment Documents. Data sources or subjects of this study are those involved in the process of making disclosure reports in terms of providing information such as the Corporate Secretary, as well as information brokers, namely analysts or Investment Managers from several securities companies. The company used as a case study is one of the companies listed on the Indonesia Stock Exchange, which is engaged in banking because it has intellectual capital like PT. Bank Negara Indonesia, Tbk.

\subsection{Data analysis}

The data analysis technique used in this case study is the interaction analysis data analysis technique proposed by Miles and Huberman (1994). The first stage is the collection of data that contains a series of data collection processes that have begun at the beginning of the study, both through interviews and preliminary studies. After the 
data is collected, the steps taken are data reduction and interpretation, which is a process of combining and unifying all forms of data obtained into one form of writing (script) to be analyzed. Chariri (2006, p.163) stated, in qualitative research, data analysis could not be separated from the data collection process. When the primary data are obtained from sources of interviews, observation, and documentation, analysis data are directly carried out in determining the next data collection.

\subsection{Data Validity and Reliability}

To establish the trustworthiness of the data, an inspection technique is required. Creswell (2007, p. 202-220) stated that there were several perspectives and conditions in qualitative validity and reliability. One of them was a perspective that used conditions that applied more natural truths, as stated by Lincoln and Guba (1985). Credibility or internal validity is a guarantee of the validity of data through internal validity, which is carried out using several criteria for testing techniques. Transferability or external validity indicated by a clear description that will enable others to recognize the location of the new research location that has similarities with the current situation and location of the study. BNI is a large company that is very well known as a company engaged in the banking business as well as a public company with a good predicate category. Dependability or reliability was done by repeating the question with the focus of the same problem. Whereas, confirmation or objectivity in this study it was shown by interviewing the subject of research analysts and the corporate secretary is done in a different place and time.

\section{Results and Discussion}

\subsection{Private Disclosure at BNI}

Private disclosure in BNI is known as the activity agenda of an analyst meeting, namely company meetings with capital market analysts, which are carried out as the responsibility of disclosing company information to shareholders. Meetings with analysts are conducted periodically every three months. The analyst meeting is a critical moment for a company to expand voluntary disclosure to reduce information 
gaps between the company and public shareholders. The Corporate Communication Division and Secretariat under the leadership of the Corporate Secretary is responsible for organizing meetings with the analyst. From observations about private disclosure activities in BNI, meetings with analysts are prepared and organized by the Corporate Communication and Secretariat Division. Meetings are usually held after the quarterly earnings announcement. BNI conducts this activity with reason to provide additional voluntary disclosure as a consequence of going public. Mr. The VM explained:

"The hope is behind analysts; for example, Deutsche, Bahana, DBS, and others, there are thousands of investors. Analysts will research companies, including BNI. Analysts, of course, can make the assessment and research from many resources, especially from this analyst meeting. The point is that the analyst meeting is held to maintain investors."

The entire Board of Directors represents the company. All staff and managers of the Corporate Communication and Secretariat Division are the teams, which is the primary support of the Board of Directors in answering questions raised by analysts. This team prepares company narratives and presentations before analysts. The narrative in the form of relevant information that is considered essential and new about the company and is expected to be responded by the analysts. The presentations and discussions are conducted with a duration of about 3 hours, followed by a meeting with business and financial journalists so that there is balanced reporting inside and outside the company.

Mr. The VM provided further explanation about this analyst meeting:

"All Directors...... full board is present and all present reports, including the Corporate Secretary. The results of the presentation are then uploaded online on the BNI website. It is like this company is ready to be naked. Question and answer sessions with analysts are an important part of analyst meetings at BNI. For this reason, BNI prepares all possibilities for questions raised by analysts."

The invited analyst will prepare the question material before attending the meeting. This is done so that there is a synchronization of understanding and stories 
between the meeting material that will be carried out at that time and the previous meeting. As stated by JT analysts:

"During the question and answer session, the analyst will provide questions and input. So before attending the analyst meeting, usually, we will open the company file, the previous research and assessment that has been released, and expectation of the company's value going forward. The term is to bring provisions. First, the invited meeting period is just empty-handed, right?"

The company does not differentiate the treatment of information disclosure against both majority and minority shareholders. Thus, explained by Mr. The VM had an interview as follows:

"On the same day, financial information was also released in the media. So, information disclosure is done as soon as possible. Moreover, BNI treats all shareholders of both majority and minority are equal; there is no difference. Even though at the General Meeting of Shareholders, the majority of shareholders must win in a vote, but at the time of treatment, the disclosure of information stays the same. While the presentation slides are corrected before publishing according to the results of discussions with the analyst."

"The bank is bound by several regulations, namely capital market regulations, BI regulations, and ministerial regulations, namely the finance minister and BUMN minister. The consequence is this weight. All reports BNI will appear online at the IDX website or securities. You can also search for it yourself in securities that you use when trading. For annual information, before being published, it must be consulted at the Commissioners meeting first. The most important thing is what the agenda is, it must be clear on what the discussion will be discussed at this meeting."

The discussion of the interview results above reflects that BNI has made voluntary disclosures. This is following Lev's statement (1992, pp. 9-32), who stated that the company's disclosure decision took a lot of cost analysis and benefits. That disclosure was made when benefits exceeded costs. Otherwise, the capital need theory suggests that voluntary disclosure helps in achieving a company's need to raise capital at a low cost (Choi, 1973). The benefits, in this case, are not only obstacles to political intervention and regulations, but also correcting misjudged stock, 
increase market finance liquidity, combination change of shareholders, and competitive superiority. Meanwhile, costs include direct cost or even various market costs and litigation potential costs.

\subsection{Narrative in Intellectual Capital Disclosure}

The company narrative produces extensive value creation that encapsulates much information. Measuring benchmarks about intangible assets subjectively and objectively is prepared in further information in the story during the discussion (Holland, 2006). Narratives are displayed on BNI slides and discussion sessions with analysts, where there is a flow of face to face information and provide additional understanding for both parties. Narratives are considered necessary by BNI in disclosing company information, as stated by Mr. VM in an interview about the importance of narration in disclosure of company information:

"Oh yeah ... definitely that. The analyst was very observant. The company must be prepared with the possibility of whatever questions are asked. Usually, they are very critical because they also did previous research. For example, about the previous hot issue that BNI Securities will be taken over by Japan, well ... at the next meeting, it will be asked by analysts, billed as such. So, a direct explanation by the Board of Directors can bring the company to a higher level of trust for the investors."

"Regarding the impact of information disclosure that exceeds obligations, this is also considered at the Board of Directors meeting. For example, whether this information disclosure has an impact on competitors and the company's business itself. By disclosing this plan and strategy, it means that competitors will know what next year will be in the company. That is one of the negative effects, even though the positive side is a lot."

From this, it can be concluded that BNI is well prepared with the positive and negative implications of the analyst meeting. Narratives are prepared to provide information that is expected to increase company value for analysts. Assets that are not as tangible as management knowledge and innovation have been a part of something more important from company value. Furthermore, the narrative is in the form of private disclosure of value creation sources and leverage of human capital and 
structural capital. Intellectual capital has developed quite rapidly and has been made easier for analysts to assess the estimated relationship between human capital and structural capital in the company. This information about intellectual capital has become an important issue in analyst meetings at BNI.

For analysts, the company's credibility is more easily understood in a dialogue in which the quality of management is the crucial trigger. Analyst, Mr. JT, stated this in the interview:

"Personality characteristics of top management, as sensitivity in aims, honesty, integrity, are critical in building trust and reputation as well as analyst confidence. It is assessed on an individual and team level of management. So, proven that the ability to produce growth, innovation, and to manage growth is as important as clear strategy and management ability in articulating it at the meeting. Managerial development plan and Policy succession are important to see how the quality of management can be flexible and changed from time to time. Information about consumption trends or the attitude of wanting to get rich can quickly be seen with direct observation of the Directors."

With the latest information, company and industry analyst will use it to recommend decisions for purchasing, holding, and selling shares to shareholders. That knowledge is an essential element for analysts to interpret information on strategy or management quality into fundamental information on the expected income, current cash, and the expected financial performance. The character of innovation change, institutional ownership concentration, financial report limitations as well as politician and other regulators' interests are all combinations of varieties in improving the essence of private disclosure channel (Holland, 1998 b). Private disclosures can reduce a company's risk estimation made by previous analysts. This was confirmed by $\mathrm{Mr}$. HSP, who gave answers in interviews as follows:

"Of course. Analysts have their own concepts about the risk that may not be the same as the company, such as projections of future economic growth. So, in this case, the analyst can confirm and clarify this matter."

The conditions in BNI support the theory of company level disclosure mapping (Alberti-Alhtaybat, Hutaibat, \& Al-Htaybat, 2012) that there are three levels 
of disclosure at BNI such as mandatory and voluntary, financial, and narrative. In this case, BNI has carried out narrative disclosures on the analyst meeting agenda, in which the agenda was carried out as an effort to minimize information asymmetry as an effort to explain the existence of managerial incentives. The next goal is to reduce market failure and adverse selection.

The message is expected to be able to get transferred to the recipient of the information, and if it is still not clear, the recipient of the information can submit questions and discussions. With analyst meetings, BNI has implemented elements of the communication process paradigm, model by Harold Laswell (1948), such as communicator, message, media, recipient, and implications. The assumption of organizational perspective from symbolic interpretation suggests that organizations produce situations/environment/culture/social reality through the meaning of interactions within the organization. Organizations are formed because of the interactions that occur among members through the meaning of symbols, both verbal and non-verbal symbols. This is where the role of communication is obvious, as well as communicating intangible asset information.

\subsection{Value Creation Process}

The three value creation processes used in corporate disclosures are hierarchical value creation (or top management), horizontal value creation (or operation), an alliance (or network) value creation. Like what happened in BNI, information about the Board of Directors turnover became the main issue that was required to be revealed in analyst meetings. Interview with $\mathrm{Mr}$. The VM provided an explanation of the importance of information regarding the change of Directors as follows:

"Information about the Board of Directors is critical. Why is that? This will greatly influence the company's image and stock price. For example, BNI will be led by a former Head of Bank [...], surely people will sell their shares, right? Likewise, for example, Sri Mulyani went home and led BNI, well ... surely people would be busy buying their shares. The impact is very big ..." 
This is similar to what was conveyed by analyst Mr. The SS in the interview is that top-level employee information is a major concern compared to the level below:

"The top-level, of course, that is more important. Take the example of Indonesia. Any macro-economic and political news will impact on the question of who the president is? So does the company. If there is news or action that is of concern, who is the Director? It is more wanted to be known than news about employee training, customer relations, suppliers, research and development, and others. A good system is important, and a good system will run if the manager is good. This is merely logic."

The hierarchical narrative reveals the driver (leverage) for value creation. These general leverages include top management quality, coherence and credibility of strategies, management remuneration schemes, and shareholder value based on company systems performance. Information with explanations in the form of narratives about the Board of Directors or the Board of Commissioners can be a benchmark in positioning BNI as a company with a strong business. Furthermore, Mr. VM explained:

"Yes, the task of the Board is to increase shareholder value. The top management has a big responsibility for that."

This view is not much different from analysts where hierarchical narratives are considered important in shaping the company's fundamentals, as stated by analyst Mr. SS about the issue of top management change as follows:

"Certainly important. Analysts will wait for the news in the hope that the replacement Directors will be at least the same level as before."

Analyst Mr. JT conveyed the same opinion with an emphasis on the Board of Directors turnover process, namely corporate governance mechanisms:

"The Board of Directors' turnover event is an important corporate strategy in the company's valuation. If we want to make a stock analysis, we will certainly see who the leader is. No less important is how the process of changing the Board of Directors is fair enough or not. Alternatively, even there is nepotism, many public companies, and even BUMN still do that. The issues of order for certain political 
parties are also important to note, considering that this affects stock prices at the time of the announcement of the change."

It can be concluded that information about the intellectual capital of human capital regarding top management is a qualitative profit-driver that drives BNI's share prices. Recruitment, training, and education of whole employees are not the center of interest for analysts unless they are related to the decision of expense in large quantities or constraints incapacity caused by lack of skilled personnel. However, the analysts are interested in how big intellectual capital methods which are being developed by the company. Abhayawansa \& Abeysekera (2009) stated that the analysts carried out an investigation of peak management vision about intellectual capital like the company's and industry's labors and how it continued to be improved. Of course, this interest varies with every company and industry. Analysts want to know every important staff or manager in the company, research \& development, and how they all are preserved, trained, and utilized to create shareholder value. This is in line with (Abdolmohammadi, 2005) stating that disclosure of intellectual capital is significant to market capitalization.

The process of creating horizontal values is typically carried out on middle management and operational level employees. This information is also part of the value creation process that shows how the company has a competitive advantage in the process of transformation against competitors. The horizontal process activities have been carried out and become routine activities at BNI. However, the disclosure of information about middle-level employees has fewer data compared to what is in the hierarchical process. Mr. The VM stated this:

"Yes, that is also important. However, the impact is not felt directly. BNI also conducts employee training, informs the number of employees, how many employees are outsourced, and others. However, for BNI, it has passed, that time has an impact too... the news has already been published, and currently, BNI does not have outsourced employees." 
Significant information revealed in the process of creating horizontal values is:

"At BNI, we see employees as an integral part of the company. Employee training is a routine and continuous activity, especially since the latest issue of fraud committed by insiders has been widely discussed. For this reason, BNI always maintains employee loyalty and integrity. The bank director may not have a disability; there is a fit and properfrom BI before the Director works officially. When he graduated, it was all seen, and the Director also received training, not only employees."

BNI applies for employee training funding as part of the company's strategy and its compliance with regulations that apply to bank business. As a business that has large human resource assets, BNI always carries out obligations to employees internally and externally. Further, the VM explains:

"In the banking business, there is an obligation from BI that a percentage of profit must be used for training employees, and it must be used up. It is, indeed, the bank's business. This expense is included in the current year's financial statements. Also, the amount of training conducted and e-learning that is accessed by employees until it can get a certificate called HCMS (Human Capital Management System)"

"Information disclosure in BNI is carried out with links that can only be accessed internally. [... showing a computer screen ...] Well, here is an example. All employees can access this. Employee evaluation was also carried out through this method, in addition to also conducting KPI (Key Performance Indicator) for all employees."

The narrative of the process of creating a network value consists of providing value drivers for all intangible assets through an alliance of supply, production, and marketing at various points in the process of creating the company's horizontal value. BNI also conducts network narrative activities in the form of attention to customers and businesses to gain customer trust in various ways, as explained by Mr. VM:

"Yes, there are reports as well. There is also a relationship with YLKI, complaints, and whistleblowers revealed with tools and equipment that become information channels. There are specific e-mails about complaints." 
Among the three value creation processes that occur in BNI, it can be said that the value creation process that provides the most significant drivers is information about top management and the Board of Commissioners or hierarchical processes. While the horizontal value creation process is also considered essential for the company, but this information is rarely disclosed during meetings with analysts unless there is very significant news. The process of creating network values is sometimes part of information during horizontal processes. In addition to the process of creating horizontal values that require more narrative explanation, analysts can find information about the process of creating value from other sources outside the company. Input results of these intangible assets are expected to provide tangible outputs such as increases in stock prices and increased financial performance. BNI strives to bring intangible assets to the company's overall strategy. This is in line with the results of the study (Beattie \& Smith, 2010). BNI showed that agency theory implemented particularly in managing human resources as the main capital of the company's operations. Management is trying to improve the company's performance by improving the main capital owned.

However, the findings of the analyst meeting interview at BNI also contradict the results of the Ulum (2007) study, which stated that in the context of the banking industry in Indonesia, the company had not maximally managed and developed its intellectual property to win the competition. The research hypothesis provides results, namely that there is statistically no influence on the average growth of intellectual capital on the future financial performance of companies. The findings/results of the study are likely caused by the acquisition of data originating only from quantitative reports disclosed by the company to the public. While the use of qualitative through private disclosure or company information disclosure. The growth of intellectual capital is carried out continuously by BNI and is part of the company's strategy in value creation.

The results of the interview above support the results of the study (Guo, Holland, \& Kreander, 2014) that banks always try to maintain communication with various parties where this relationship is long term because banks rely on trust in business. 
Besides, bankers and analysts have their preferences and different views on intellectual capital, where the bankers are not easily understood by the analysts (Chen, Danbolt, \& Holland, 2014). However, BNI always strives to continually adjust its business with changes in the business environment, such as IT development at this time.

\subsection{Market Changes and Company Conditions}

The ongoing economic changes and performance of public companies have provided considerable evidence of how the story of a company is treated in the external environment from time to time. Companies must make strategic decisions and respond to macro and competitive changes. The company can take corrective actions for the previous six months or more, or income reports in the last period, to maintain trust and credibility of the current management (Holland, 2009). These actions are essential to do in maintaining analyst confidence. The firm's value is understood as the output current of the company's fundamental complex combination that is connected in the form of income in the current period, growth prospects based on track record, and trust in the company.

The consistency between the strategy and the results of the company's performance is also the main concern of analysts in the discussions with the companies. The performance also experienced changes in line with market trends and the company's internal conditions. For analysts, understanding the changes in the company is a necessity as a consideration in carrying out analysis and recommendations of shares. One of the analysts interviewed by Mr. JT stated:

"We are always concerned with management performance. Like the local election campaign, promises with realization must match. Management has promised to make improvements or increase profits, for example ... then where is the realization? That is all we bill. If there is a discrepancy, we will ask why. Not the justification or self-defense of management that we are looking for, enough honest confirmation of the failure to achieve that target. Back to morality." 
The discussion of market changes and the external environment above leads to the statement of Kaplan \& Norton (2004, p.65-127) that in the period of the late twentieth century, several researchers and companies believed that the management of operations was the most crucial component in the organization's strategy. The results of research on the achievement of manufacturing companies in Japan engaged in transportation, electronics, and the optical industry have placed a high priority on redesigning, rearranging, and continuous improvement as an essential operational process. The company's efforts to achieve the superiority of operations have achieved great success. Without operating excellence, the company will have difficulty executing the strategy.

On the other hand, market information gets in the process of value creation, which is changing fast enough from time to time. The information market primarily focuses on large companies. This can be seen in many analyses of large companies involved in disclosure problems and valuation problems observed in the post-2000 financial crisis (Holland, 2009). Figure 4.1 explains that market feedback information comes from two sources, namely; the capital market and the information market. In the capital market, companies receive special feedback about changes in stock price performance relative to direct competition, larger regions, and markets as well as information on broader changes in market sentiment. The position of the company is calculated from a comparison with the weighted average market indication. Stock prices and other numerical market feedback are always a further boost in the market as feedback from analysts inface-to-face meetings or private disclosures.

For BNI, analysts are betting that the company's value is in line with changes in the information market and capital market. This is a strong reason for holding a meeting with analysts at BNI. With the meeting, BNI will get better information about changes in the information market and capital market, so that anticipation of changes is expected to be appropriate and have a positive impact on the company, as explained by Mr. VM: 
"BNI dynamically exploits knowledge about value creation and in the context of change. Real market changes and financial markets are often a means of disclosing information content, to allow analysts to conclude narratives, then examine and compare them with previous presentations and track records."

BNI also takes precautionary measures to change the analyst's actions and follows up on any major analyst actions, as explained by Mr. VM:

"The bank is bound by several regulations, namely capital market regulations, BI regulations, and ministerial regulations such as the finance minister and BUMN minister. The consequence is this weight ... For example, for CSR, there is a minimum of costs incurred as regulated in the Minister of SOE Regulation Number PER-5 / MBU / 2007, which is 4\% of the profit. If you do not implement $i t$, the company's reputation can go down."

"Stock prices as an impact of the results of analyst valuation are the main indicators to what extent the company is interested, valued, trusted by shareholders. If stocks are seldom transacted, they are less attractive to investors. So, it is not only the price value, but the volatility and frequency of trade is also an indicator of whether BNI shares are valued properly, this continues to be maintained by BNI. Why do stocks go up? Surely people believe, many save their money in the bank. So, this has something to do. The shareholders will quickly respond to the earnings announcement, and the continuation of that, the business operation must be maintained. In the disclosure, BNI has done what must be done, and what should be done, as well as additional information exceeding competitors."

Signaling theory holds an essential position in various management literature, including human resource management. BNI points out that one of the benefits of the analyst meeting agenda is momentum for profit. Capital markets and regulations continue to change in terms of information needs. Deegan (2007, p.434-450) states that individual behavior is based on a branch of psychology called behavioral decision theory, which has branches of cognitive, economic, and statistical psychology. Users of information use their simplified investigations when making special judgments. Companies must be able to anticipate how users will react to a disclosure in the form of special disclosures such as analyst meetings at BNI. 


\subsection{Dynamic Characteristics of Disclosures and the Role of Input Analysts}

Analysts use various ways to interpret new information and event, which appears to determine the meaning of external messages sent to the company. Furthermore, conclude the company disclosure, which has the potential means for users in the market. This provides insight into the effectiveness of analyst internal decision making, especially if there is a track record relating to managing the quality of intangible assets. Analysts will link the forecasting they have made before with the achievements of the company (Abhayawansa \& Abeysekera, 2009). Not all analysts have the same perception about the importance of the narrative in private disclosures, such as an analyst's explanation, Mr. SS, in the interview, said:

"Helpful enough, but not too much. The important thing is that we know the track record and integrity that has been maintained so far by the company. Some groups even make mistakes in disclosing normal financial information. Well, like this, the analyst must know first. Sort out first which companies with a good reputation and a bad reputation. Again, analysts must realize to treat stocks as an investment tool, which with a realistic return. Do not be hyperactive for trading, buying, and selling that does not have to be done every day. Do not forget the transaction costs if you are too active; psychological costs are also a certain measure."

Analysts ask for clarification to the peak management at the meeting. That is the question of why they do certain activities, what exactly they do, and How they do value creation activities. Understanding about narrative value creation process can be seen as the core of the internal management process that is also important in the external disclosure process. Differences in understanding with companies can be resolved in discussions and explanatory narratives, which allow analysts to make corrections to previous company evaluations. Analyst Mr. HSP gave the interview answer as follows:

"It is very likely that analysts will make corrections to valuation if new information is obtained. From the questions put forward, it will provide much input for analysts. Yes, true. New information that had not yet been obtained can change the assessment and expectations which have been made for the company. That is okay." 
This proves that, like a company, analysts also have a dynamic nature of company information content. The flexibility of both parties is reflected in the publication of each party's information to users. Also, analysts get the advantage of knowledge about the company more precisely and deeply so that it can help to make valuation decisions and stock selection. This time-based learning is justified by BNI and analysts as well as interviews with research subjects (Figure 4.1)

Mr. VM:

"Yeah, sure ... Both parties get many benefits from the narrative and the discussions that are conducted. Analyst valuation comes from the information revealed. The company also knows the ongoing market information needs."

Mr. HSP:

"Of course. With direct discussion, analysts can better understand the company's intent and strategy. Especially if the presentation concerns the company's latest news, here analysts can extract more information."

"Input can certainly be given. Nevertheless, the disclosure of this information also has limits regarding secrecy in the context of competition and others. As long as the input is considered positive and does not belong to a category classified as confidential, nothing is revealed. All companies keep their secret weapons."

The results of the interview above support the statement of Abhayawansa \& Abeysekera (2008) that the disclosure of intellectual capital is identified in two focuses, such as companies and analysts. With a face-to-face meeting between the two parties, the company can find out the additional information needs desired by the analyst. Analysts are essential mediators for BNI. Analysts who are present at analyst meetings and provide input and questions to companies in discussion sessions are the main ingredients of corporate learning.

Changes in the environment, including problems of fraud that were ever experienced by BNI, has become a matter of learning and enterprise environment knowledge. In addition to market changes and the conditions of the banking industry, such as the increasing need for ATMs, Credit Cards, special customer services, agency 
cooperation efforts with insurance or mutual funds, expansion of customers to foreign countries, sharia business alternatives, etc. BNI has also been anticipated, so it does not become a stuck-in-the-middle company amid change. The changes in the environment above are also accompanied by an increase in knowledge or sophistication of shareholders, causing a change in demand for information in the capital market. Analyst meeting in BNI also allows the role of input from analysts in discussions in order to provide corporate learning.

Figure 4.1

Capital Market Changes, Information Market Changes, and New Questions for Companies

\section{Capital market Changes in: \\ 2. Market for information changes:}

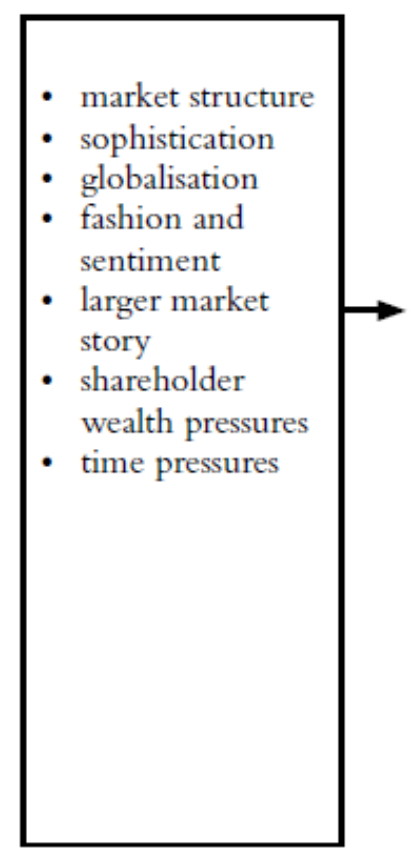

Fund managers (FM)

$\&$ analysts assess market changes and how this increases the information demands at the four information processing levels:

- valuation level and mosaic

- portfolio or sector level

- FM/analyst valuecreation chain level

- market story level

And assess how changes exacerbate problems of:

- processing intangibles information at these levels

- conflicts of interest, price sensitivity and bias at these levels
3. New questions and new perceptions:

Company

continuously assesses new questions and feedback from analysts and fund managers

This process changes company perceptions of what is value relevant information and hence what should be disclosed

Source: Holland (2004) 
The response made by BNI with the analyst meeting agenda, the use of social media as one of the disclosure tools, and the speed of publication on the website are proof of the form of structure, narration, and information on contextual information. It does not rule out the possibility that sources of information from public areas have limitations. For example, the ratio calculation made by one source may be different from other sources so that as if the numbers produced by one source are better or vice versa. Analysts must be aware of differences in the basis of these calculations so that no misleading information is made.

The company's financial statements also have different measurement and presentation bases and different industry conditions. The accounting standards used are possible for these differences. Increasingly stringent standards limit financial statements, and the generally accepted accounting principles are increasingly rigid financial reports dominated by financial data and give less important qualitative data on a field like management quality. Holland (1999, p. 7) stated that due to these limitations, collection and processing information public by itself were not also expected to be useful in identifying cheap or expensive stock. Public information spread and not focus enough for analysts for using it in the company's judgment or influential strategy and the governance company and getting closer to zero benefits and limited quality public information recognized as main obstacles for analysts to perform actions.

Analyst Mr. SS provided an answer to the lack of disclosure of public information. However, analysts can get around by making big-cap stock selection decisions in interviews as follows:

"That is lacking. However, we can understand because nothing can be ideal in the company. They can have many interests."

"Yes, one way is to select stocks with large capitalization. It is clear. That can help investors not get caught up in misleading information about the company. A large company cannot take actions that are detrimental and reduce its reputation." 
While analyst Mr. HSP had an opinion on the limitations of public information from a comprehensive perspective:

"Useful enough? Yes. Comprehensive? Maybe not yet. Analysts need more detailed information about corporate action going forward as to what the details are"

The analyst argues that they need other specific information in company valuation, and this is not possibly found from financial, public announcements reports publication company, and other public sources. Limitations of public sources give a strong incentive for analysts to participate in developing the company's private sources information. At BNI, analysts can find the information director of the company through the Investor Relations channel. Other analysts explain information from stock trading, which can be another consideration as stated by analyst Mr. JT:

"So, that must be tricked by investors and analysts. Analysts must know from the limitations of that information, which ones are quality and relevant to the market. For liquidity and market capitalization, which frequency and volume of trading are good, automatically those stocks can be chosen. Volatility can help filter stock valuations. So, do not rely too much on financial number information. The point is to find good stocks at a reasonable price. Do not speculate analyzing bad or fried stocks."

According to the market efficiency hypothesis, the Indonesia Stock Exchange is included in the category of strong efficiency. One supporting indicator is that investors have private information that is not reflected in the stock price. A discussion of the results of the interview above is following the results of previous studies about the decreasing or increasing relevance of financial statement information. Collins, et al. (1997), Francis and Schipper (1999), and Brown et al. (1999), who had measured the extent of the relationship between stock prices and financial statement information. Research that tends to assume that market participants capital is the primary financial statement information, and sometimes when they ignore the need for financial information that is reliable and verifiable. This result also supports the statement (Holland, 2014) that analysts have different styles in finding and processing 
information to minimize the level of uncertainty in the portfolio they are building. Analysts (MI) always look for ways to improve portfolio performance and reduce costs for information on their investments.

\section{Conclusion, Implication, and Limitation}

\subsection{Conclusion}

Based on the findings during observation and depth interviews as well as discussions as presented, some conclusions can be drawn as follows:

1) Private disclosures at BNI were presented in the form of analyst meetings. Meetings with analysts are conducted periodically every three months after the announcement of earnings. The analyst meeting is an essential moment of the company as an effort to expand voluntary disclosure to reduce information gaps between companies and public shareholders.

2) The information revealed is the one relating to three processes of value creation, such as hierarchical, horizontal, and network, where the hierarchical process becomes essential core information to be revealed. The disclosure agenda includes the entire value creation agenda, which consists of information about the role of key intellectual capital in those three processes of connected value creation. Information about the succession of the Board of Directors is the most important issue for BNI, in addition to issues regarding employee training and customer management.

3) Narratives and information on benchmarking intellectual capital, corporate innovation, and reputation management expertise are important qualitative information communicated through oral narratives, texts, slides, and diagrams. With the narrative of the company, analysts can better understand the relevant information content subjectively and objectively so that it will facilitate the assessment process and the provision of information in connection with stock selection decisions.

4) BNI has anticipated that changes in information needs at the market level have changed the company's tasks at this time, and therefore changed the nature of 
the structure, narrative, and contextual disclosure of information made by the company. Market changes also contribute to increasing problems of conflict of interest between analysts, as well as problems in providing sensitive information about price.

5) Analysts view the need for information directly from companies to be used to reduce information asymmetry and changes in the information market and capital markets. In an analyst meeting held by BNI, analysts are more flexible in providing input and questions. Changing quality information content provides a way for analysts to deal with the dynamic needs of private disclosure.

6) Analysts have difficulty applying financial theory and company valuation, as well as limited information from public areas. BNI answered the difficulty in response to changes in the information market. However, as a public company with the largest composition of ownership by the government, BNI is experiencing pressure from implementing regulations that require changes in new compliance mechanisms.

\subsection{Implication}

The role of the regulator is critical, particularly in guiding private disclosures originating from changes in information requests and responses from information providers. The government must be responsive and gives flexibility in determining disclosure standards and uniform perceptions for the company.

\subsection{Limitation}

Cases/phenomena carried out only in one company are intended to explore further the process of value creation in the narrative disclosure carried out because the emphasis in this research is the case in question, not the choice of the company. Another limitation found in the disclosure element that was explored, and excavation was more focused on one type of voluntary disclosure method like private disclosure. Subsequent research on narrative information content in disclosure of private 
enterprise can be developed further in the information on the needs of various stakeholders. Relevant information that can still be extracted is, for example, related to sustainability reports. PT. Bank Negara Indonesia Tbk is recommended to expand further disclosure regarding IC as a business transformation effort in the financial statements as the nature of the industry that is owned and relying on human resources.

\section{Reference}

Abdolmohammadi, M. J. (2005). Intellectual capital disclosure and market capitalization. Journal of Intellectual Capital, 6(3).: 397-417

Abhayawansa, S. \& Abeysekera, I. (2009). Intellectual capital disclosure from a sell-side analyst perspective. Journal of Intellectual Capital, 10 (2): 294-306

Alberti-Alhtaybat, L. v., Hutaibat, K., \& Al-Htaybat, K. (2012). Mapping corporate disclosure theories. Journal of Financial Reporting and Accounting, 10(1): 73-94.

(2016). Investor relations via Web 2.0 social media channels: A qualitative study of Middle Eastern corporations and investors. Journal of Information Management, 68(1): $33-56$

Arnold, J., Moizer, P., \& Noreen, E. (1984). "Investment Appraisal Methods of Financial Analysts - A Comparative Study of US and UK Practices." The International Journal of Accounting, Spring: 1-18.

Barker, R. (1997). "Accounting Information, Corporate Governance, and Stock Market Efficiency: A Study of Information Flows Between Finance Directors, Analysts, and Fund Managers." BAA, March 2. Birmingham.

Beattie, V., \& Smith, S. J. (2010). Human capital, value creation, and disclosure. Journal of Human Resource Costing \& Accounting, 14(4):262-285

Brown, S., Lo, K., \& Lys, T. (1999). "Use of R2 in Accounting Research: Measuring Changes in Value Relevance Over the Last Four Decades". Journal of Accounting and Economics 28: 83-115.

Chariri, A. (2006). "The Dynamics of Financial Reporting Practice in an Indonesian Insurance Company: A Reflection of Javanese Views on an Ethical Social Relationship." Not published dissertation. Australia: University of Wollongong.

Choi, F.D.S. (1973) Financial Disclosure and Entry to the European Capital Market. Journal of Accounting Research, 11, 159-175. 
Chugh, L., \& Meador, J. (1984). "The Stock Valuation Process: The Analysts View". Financial Analysts Journal, Vol 40: 41-48.

Collins, D., Maydew, E., \& Weiss, I. (1999). "Changes in The Value-Relevance of Earnings and Book Values Over The Past Forty Years". Journal of Accounting and Economics 24: 39-67.

Denzin, N. K., \& Lincoln, Y. S. (2009). Handbook of Qualitative Research. India: Sage Publication.

Francis, J., \& Schipper, K. (1999). "Have Financial Statements Lost Their Relevance?". Journal of Accounting Research, 37: 319-352.

Guttman, I., Kremer, I., \& Skrzypacz, A. (2012) Not Only What But also When: A Theory of Dynamic Voluntary Disclosure. Vol. April Stanford University.

Healy, P. M., \& Palepu, K. G. (2000). "A review of The Empirical Disclosure Literature". JAE Conference, Harvard: Harvard University: 1-59

Holland, J. (1998a). "Influence and Intervention by Financial Institutions in Their Investee Companies". Corporate Governance, 6 (4): 249-64.

(1998b). "Private Disclosure and Financial Reporting". Accounting and Business Research , 28 (4): 255-69.

(2001). "Financial Institutions, Intangibles, and Corporate Governance". Accounting, Auditing \& Accountability Journal , 14 (4): 497-529.

(2004). Corporate Intangibles, Value Relevance, and Disclosure Content. Edinburgh: The Institute of Chartered Accountants of Scotland, ICAS Research Report.

(2006). A Model of Corporate Financial Communications. Edinburgh: The Institute of Chartered Accountants of Scotland, ICAS Research Report.

(2009). "Looking Behind The Veil: Invisible Corporate Intangibles, Stories, Structure and The Contextual Information Content of Disclosure". Qualitative Research in Financial Markets, I (3): 157-187.

Holland, J., \& Johanson, U. (2003). "Value Relevant Information on Corporate IntangiblesCreation, Use, and Barriers in Capital Markets - Between a Rock and a Hard Place". Journal of Intellectual Capital, Vo. 4 No. 4 (special issue): 465-86.

Kaplan, R. S., \& Norton, D. P. (2004). Strategy Map: Converting Intangible Assets into Tangible Outcomes. Boston, Massachusetts: Harvard Business School Publishing Corporation.

Laswell, H. D. (2009). Power and Personality. New Jersey: Transaction Publishers. 
Lev, B. (1992). Information Disclosure Strategy. California: Management Review.

Luthy, D. H. (1999). "Intellectual Capital and Its Measurement". Symposium on Measuring and Reporting Intellectual Capital: Experience, Issues, and Prospects. Amsterdam: OECD: $1-18$

Marston, C. (1996). Investor Relations: Meeting the Analysts. Edinburgh: ICAS.

Marston, C., \& Shrives, P. (1996). "A Review of The Development and Use of Explanatory Models in Financial Disclosure Studies". EAA. Bergen.

Miles, M. B., \& Huberman, M. (1994). Qualitative Data Analysis: An Expanded Sourcebook (2nd ed.). California: Sage.

Organization for Economic Co-operation and Development (OECD). (June 1999). "Guidelines and instructions for OECD Symposium". International Symposium Measuring Reporting Intellectual Capital: Experiences, Issues, and Prospects. Amsterdam: OECD, Paris.

Scott, W. R. (2009). Financial Accounting Theory. Toronto: Pearson Prentice Hall.

Ulum, I. (2007). "Pengaruh Intellectual Capital terhadap Kinerja Keungan Perusahaan Perbankan di Indonesia". Tesis Tidak Dipublikasikan. Semarang: Magister Akuntansi Universitas Diponegoro.

Watts, R. L., \& Zimmerman, J. L. (1985). Positive Accounting Theory. Prentice-Hall. 